\title{
The Dimensions of Oil Conflict and Impact on Nigeria's Federal Relations: A Review
}

\author{
Akume, Albert. T. \\ Department Of Public Administration, CASSS, Kaduna Polytechnic, Kaduna, Nigeria. \\ yimaalbert@yahoo.com
}

\author{
Doi:10.5901/mjss.2014.v5n10p222
}

\begin{abstract}
Conflict is a natural human phenomenon. Its impact is however variegated and dependent on how it is handled. Nigeria is encumbered by conflicts that are occurring along political, social and economic fronts. Oil (petroleum) is an economic resource relevant to Nigeria's development but the disruptive disagreement, discontent and contention oil has continued to generate due to some perceived unfairness has made oil conflict to transcend economic, politics and social lines such that the entire national polity is tensed with strained relationships between groups on the one hand and on the other hand between groups and the state. This disagreement has significantly impaired Nigeria's developmental process. It is against this backdrop that this paper utilizing the documentary method and analytic approach examines the dimensions of oil conflict, the modes of its resolution and its impact on Nigeria.
\end{abstract}

Keywords: Oil, Conflict, Interest, Frustration, Deprivation, Derivation, Militancy, Amnesty, Niger-Delta, and Resource Control

\section{Introduction and Background to the Paper}

Oil (petroleum) and conflict remains a thorny issue for governance in Nigeria. In spite of the extensive literature that has emerged recently the subject is by no means exhausted neither is scholarly interest in any way diminished. This is due to the continued contestation and its associated challenge that conflict in this sector and the Niger-delta area has continue to throw at state effort to create a less tensed polity necessary for private investment the sector. The continued presence of conflict in this sector is indicative that the hitherto mechanism utilized to manage the situation was grossly inadequate to resolve the main issues that triggered the contention. The situation however has to change. Change is a fundamental element of social progress, change is a constant phenomenon which must be embraced and nurtured for a less strained polity. When protagonists of resistance to oppression and resistance to change fail to engage in a meaningful dialogue, their conversation could easily degenerate from a dialogue of the deaf to a dialogue of the deaf and blind, which invariably leads to a systemic breakdown. Thus, it is the responsibility of the proponents of resistance to change to engage their opposing parties in a transparent and constructive dialogue leading to a peaceful resolution of their conflicts (Natufe, 2001:1).

Although, conflict is an integral aspect of social existence; it could be functional or dysfunctional depending on how it is handled. Conflict as an event is not an independent phenomenon; it is a reaction to some perceived inconsistency in relations which gives one group advantage over the other groups in society. Conflict is triggered by groups' inability to balance their interest at the negotiation table in a fair and open manner. In Nigeria's case the cause of most of the persistent conflicts can be said to be fuelled by unfair resource exploitation, resource distribution and resource use; and this resource is oil (petroleum resources). For the Niger-Delta communities however the main cause of conflict is the feeling by the local population that they are marginalized and deprived of a just share of the benefits (IDEA, 2001:237) from oil resources derived from their locality.

The scope of oil conflict far transcends the immediate communities from where it is exploited; it has taken a national dimension and it reclines behind the rise of community politics (Allison, 2003:101) not just within the Niger-Delta alone but in other communities outside the region. The dimension of oil conflict in Nigeria has over the years been felt on both the vertical and horizontal axis with destabilizing repercussion for the Nigerian state. It is responsible for weakening the already tattered fabrics of Nigeria's federal relations and thus threatened the basis for national cohesion and unity and significantly constrained the foundations of stable growth and socioeconomic development (Jega, 2007:203). Not necessarily because it is a major revenue earner for Nigeria but because its exploitation and the redistribution of its benefit among groups by successive government is perceived to be unfair. This is because the pattern of distributing its proceeds is skewed and arbitrary determined such that it gave advantage to some groups and section of the Nigerianstate over others. This process was possible due be to the fact that whosoever controls the vortex of state power in 
Nigeria control the distribution of its proceeds in ways he/she deemed fit with impunity given that the state is the main allocator of resources and also set the terms for such distribution (Elaigwu, 2005:41).

This singular factor has continued to supercharge the process of political engagement in Nigeria such that the rules governing the political process is constantly been change to suit the wishes of the governing hegemonic class that benefited from such arbitrariness. The continued refraction of due process birthed discontent and the rise of harmful community politics that placed a serious strain on the cord of nation unity and common values. The lost of trust in the state has been replaced by expressed sectional ties and values. The consequence is that Nigeria is a society with a strong communal loyalties rather than a national civic realm. All this social dynamics and changes have combine to aggravate the existing oil conflict. It is against this backdrop that this paper examines the dimension and dynamics oil conflict, the various modes to its resolution and the overall implication it has on federal relation in Nigeria. The question this paper wants to answer is what dimension has this conflict taken? Why has this conflict persisted and what is its impact on Nigeria's federal relations?

\section{Oil Conflict: Cause and Issue}

Nigeria is a nation whose history is rich in conflict with oil contributing significantly to it. Oil is at the heart of the 1967 Eastern region's bid for succession which subsequently resulted in the bitter and regrettable three year civil war. Aside from the events of 1967-1970, oil is in part responsible for the inordinate political power struggle, the national question, resource control and militancy due to some perceived abnormalities in its management. Whatever the nomenclature attached to conflict it is a by-product of goal incompatibility for which the divergent groups presume that their differences are irreconcilable or a situation whereby each group feel that the actions or inaction of the other groups threaten the attainment of their valued interest. Going beyond this perspective, conflict evolves from deep-rooted moral or value differences, high-stake distributional questions, such as who dominates whom; where the fundament human psychological needs for identity, security and recognition are often at issue as well. Conflict as a charged state of human emotion could be latent or manifestly expressed; hence, it is a semiotic sign used as a medium or instrument of communication (Gandu, 2005:131).

There are plethora of theories that illuminate our understanding of the various perspectives to conflict. Conflict theories as they may be referred to are perspectives in sociology that emphasize the social, political or material inequality of a social group, that critique the broad socio-political system (Wikipedia, 2013). These theories are cupped in the modernization, the capture, the reactive/defensive mobilization, the resource completion, the political economy and the failed state theories. The thesis of these theories summarizes yet explains coherently the inherent dynamics of oil conflict. However, a better description of the Nigerian situation as it relates to oil and it associated struggles is better by the captured reactive defensive mobilization and the resource completion theories. The capture theory depict the reality of a developing society where one dominant group within a constituent either local, state or federation seek to monopolize power based on an erroneously preconceived notion of its right to it. The resource competition theory however mirrors the struggle for resource acquisition that evolved due to twisted community politics that projects sectional interest over national interest.

The reactive/defensive mobilization theory's argument is couched around the evolving dynamics that characterize the distribution of societal resources (wealth, power and prestige) based on some skewed criteria which consequently birth disaffection between groups in society. Arising from such inequity reflected in resource distribution is the emergence of two opposing groups; the core and the peripheral (Ekpekurede, 2005:108-112). The relationship between the core and the peripheral is one that the core group (who is the principal possessor of state power and thus control resources) exploit, dominate and even annihilates the peripheral groups. This self-centric attitude of the core group triggers the peripheral groups into collective action (Ekpekurede, 2005:109) using whatever mechanism possible to correct perceived inequity and injustice. While collective action has its benefits, the problem however with it is that it most often creates a situation where the uncoordinated actions of each player may not result in the best outcome he or she achieves (Whitefield, 2003:89).

These theories combined amply capture the oil generated conflict between the Niger-Delta, other opposing groups and the federal government. The persistent issue of oil conflict is a consequence of government arbitrariness and inaction to respond to call to correct identified injustices in the distribution of oil revenues. This failure occasioned the rise of scattered pockets of militant groups operating uncoordinatedly at different different states in the Niger-Delta. Equally relevant to the struggle are the individual protest lead at intervals by the affected communities on the one hand and the governors on the other hand. Each of these groups used different tactics and on different platform but presumed to be pursuing the one cause of liberating the Niger-Delta from federal government injustice. Sadly however, the discordant 
mass of actors had different interest and used methodology that rather compounded the problem of the Niger-Delta as such the result of the uncoordinated struggle birthed clashes between the different groups presuming to be fighting for the cause of the Niger-Delta. As a corollary, the goal the Niger-Delta groups set-out to achieve continued to drifted further and further away to say the least. This is not to say that the disjointed struggles failed entirely to achieve some minimal goal because it drew attention to the plight of the oil-producing communities. It is however evident that the arm struggle and violent protest remain costly than the minimal gains achieved. The attention provoked both the state and the federal government to stand up to its responsibility of developing the Niger-Delta communities on the one hand. On the other hand, it led to the proliferation of small arms that is now been used by criminal groups to terrorized the Niger-Delta communities. The general insecurity in the region impeded investment and employment creation necessary to speed-up the socio-economic development of the affected communities. It then holds that the result of the scattered collective action by the people of the Niger-Delta against perceived injustice is mixed.

The one instrument that strengthened and facilitated the mobilization of local communities in the Niger-Delta for agitate against exploitation, alienation and exclusion is community politics. Community politics draws on the identity of the local community and its shared interests, particularly those that had to do with preserving and enhancing the local environment, and helps build the community by making people more aware of those interests and by raising their estimation of the relative importance of local issues (Allison, 2003:101). Organizing at the local level by the people to project issues of local importance for national attention for constructive engagement is a dimension of political participation. It is an important avenue for aggregating public opinion necessary in aiding government to rightly determine the particular interest of that collective and the issues that concerns them so that it can be properly resolved. In this sense community politics is a veritable instrument for gingering a sense of belonging and national cohesion. Contrarily, if it is used by local leaders to stir-up sectional or primordial sentiment community politics then becomes a tool for conflict because under such condition each group perceives the other groups interest as petty or dog dirt (Allison, 2003:101).

In most case, the inability of the state to integrate those divergent interests into a single mold has consequence for alienation and exclusion in the governance process of a significant proportion of the population. For the majority of the exploited, alienated and excluded community politics becomes a rallying point for community agitation which if not quickly resolved via engagement and participation inflame group frustration and conflict. This to say that if the political process is not appropriately opened to accommodate the excluded sectional mobilization take on a disruptive violent dimension that undermines national progress. This is premised on the truth that alienation births oppression and oppression is a reality of a political struggle. Its continued manifestations compel a people to revel in their historical past as they compare the way they were with the present. This historical retrospection influences their politics. For them, History becomes an intoxicant for social and political activism, depending on where we stand on the spectrum of oppression; History can provoke us to adopt positions inimical to peaceful resolutions of conflicts. The vigour of ethnicism or nationalism in Nigeria, especially in the Niger Delta is explainable in History. The conflict of interests is perceived as a challenge to the legitimacy of ethnic or nationalistic claims to power and authority (Natufe, 2001:1).

Given the depth of their deprivation and frustration because of the mode of resource distribution on the one hand and neglect on the other hand, the governors of the Niger-Delta states had opted for resource control. The seemingly local agitation by local militia however degenerated into the destruction of pipelines with the intent of stalling oil production. The intensification of violence in the Niger-Delta is not unrelated to feeling of deprivation that while they supply Nigeria's goose as it were they wallow in squalor and poverty (Elaigwu, 2005:41).

Ostensibly supporting the above observation it is evident that this region which is home to Nigeria's oil wealth remains the most impoverished community in the nation lacking in basic infrastructure-good network of roads, health-care facilities, good schools and portable water. In deed the Niger-Delta region is underdeveloped (Duru, 2009:259-264). Provoked by these poor conditions, the Niger-Delta communities had to express their dissatisfaction via collective protest given that peaceful engagement had failed to produce the right result. Their restiveness started on a mild note with pockets of peaceful demonstrations to the offices of multinational oil companies by local community development committees of the various host communities; but due to the their neglect and the manipulative character of the multinational companies and the government the hitherto peaceful protest soon degenerated into lock-ins and seizures of oil installations. By 1998, the Niger-Delta region had become a lawless zone where youth disrupted oil production activities and communities frequently engaged with little provocation, in destructive inter-and intra-community strife (Duru, 2009:256).

Compounding the complex situation of the Niger-Delta region is the problem of their leaders' greed. Most of the socalled Niger-Delta community leaders preferred to connive with the government and multinational organizations operating in the areas to undermine the legitimate demand and agitation of the host communities against the deplorable environmental degradation and neglect for its correction. The amoral character that became a part of the struggle rather 
undermine genuine progress to be made in proffering, adopting and implementing the most appropriate solution in solving the problem of the Niger-Delta long before 2009. The impact of the violence in the Niger-Delta arising from their frustrations has continued to hit had on the oil dependent Nigerian economy causing a significant fall in capacity utilization, low production output and low national revenue. The heightened insecurity in the region did not help matter either.

\subsection{Dimension of Oil Conflict in Nigeria}

\subsubsection{Oil and Vertical Conflict in Nigeria}

The vertical dimension of oil conflict in Nigeria is deeply rooted in the process, criteria and principles used in the redistribution of revenues accrued from oil among and between the federating units. It is a process which has its root in the history of revenue sharing in Nigeria. Suffice this paper to note that the two defining principles by which revenues are to be distributed are equity (political consideration) and efficiency (economic and compensatory considerations). Balancing this two divides is a pretty crucial and difficult decision for third world government that need all the revenue it garner to pursue her development objectives. Despite this need, fairness requires that in the process of revenue allocation equity consideration should not in any way override economic consideration. This is necessary to encourage the continued production of the right quantity and quality but also as a compensation to take care of the negative externalities arising from the impact of producing that revenue generating commodity in the localities were those productive activities are conducted. The paradox in Nigeria that has continued to generate conflict between the federal, state government and the oil producing communities is that the application of this principle in revenue sharing is defined by political/equity over economic/ efficiency criteria. Consequently, the source of the heated contestation revolves around the question of how equitable the sharing of resources (Jega, 2007:209) is.

Although, the allocation of revenue to the various levels of government after 1946 was premised on the strong bargaining powers of the regions, the derivation principle was still at the epicenter of the sharing process. The important place accorded to the derivation principle in the redistribution of federal revenues waned significantly when the military began the centralization of the federal state after the Nigerian civil war in 1971. At present S162(2) of the 1999 as amended stipulates that in determining the formula, the National Assembly shall take in to account, the allocation principles especially those of population, equality of states, internal revenue generation, land mass, terrain, as well as population density: provided that the principle of derivation shall be constantly reflected in any approved formula as being not less than thirteen per cent of the revenue accruing to the Federation Account directly from any resources. Though it is reflected in the constitution the oil producing states are not fully remitted the constitutionally prescribed 13 per cent. Theoretical, the justification for transferring revenues from higher to lower tier government in a federation are: for balancing purposes, to achieve equalization, and to provide an incentive (Jega, 2007:209) to facilitate balance development. It should be noted that the derivation criteria is a useful instrument for providing such vital incentives. Ironically, however, after the centralization of fiscal matters in the hands of the federal government derivation was systematically relegated to the background while other criteria mentioned above were accorded greater importance in the sharing of federal revenues among sub-national units.

The derivation principle has remained a contested issue in Nigeria fiscal relations. It has remained one of the mismanaged and maligned criteria since the decline of agriculture as a major revenue earner and in its stead, the rise of oil as the major source of revenue earner for Nigeria. It has continued to generate tensed conflicting relations due to the demand by oil producing states for its generous application and the equally strong call for its de-emphasis by non-oil producing state. The non-oil producing states argument for its de-emphasis is couched callously on the grounds that the principle is not easy to apply because the burden of tax collected within a state is not necessary borne by the residents of that state alone. Another argument against the derivation principle rest on the lack of precise statistics relating to the regional distribution of imported item for which to use in sharing revenues derived. Nonetheless, is the argument that the full use of the derivation principle will accentuate uneven development between states in Nigeria (Abonyi and Akume, 2009).

The relegation of the derivation principle coupled with the arguments against the principle only evidence a sinister and mischievous intention by the ruling hegemony to continue to systematically control public wealth and control of state power while the minorities are blocked from benefiting generously from oil wealth and the power associated with. In a federal state the question of even development is not an issue because each state has its individual right to choose the path of its development with less interference from the central government. The direct enforcement of the principle of equal development for all the states under whatever guise is a direct negation of the federal principle. More so, the 
derivation principle should not only be viewed as a motivation for the production of revenue yielding commodity but as a means of catering for the abnormalities left (Eguaikhide and Omo 1999: 101-115) behind in the process of creating those revenue yielding commodities on those communities that bear the burden of such negative externalities.

De-emphasizing the generous use of the derivation criteria means significantly reducing the revenue generating capacity of those communities from where oil revenue is derived. This is a direct conspiracy against those states. Aside from the conspiracy of the non-oil producing states to reduce the influence of the Niger-Delta although, being the goose that is laying the golden eggs. The federal government led by the military is not guiltless in the whole scheme of things. It should be noted here that the immediate intention of the federal government after the Nigerian civil war was to centralize all aspect of fiscal relations as a means of breaking the stronghold of the very powerful three regions each controlled overwhelmingly by ethnic groups (Ibeanu, 2008:202); sadly the Niger-Delta became worst affected after 1960 as it became dominant due to oil.

The irony in the whole issue of centralization of revenues in Nigeria's federation is that many ethnic minority elements in the Niger-Delta were proponents of centralization of revenues in the 1960s before oil was discovered in the region. Hence their hitherto calls for centralization of revenues has since then become the albatross for ethnic minority interests in the Niger-Delta (IDEA, 2001:247). The desire to build an egalitarian society should not rest only on the anvil of equality and balance development but also on the parameter of economic efficiency. This is necessary if the process of solving this problem is not to result in aggravating one section of the federation against another as it were hence, making the contention recurring thorny issue in Nigerian federal relations.

\subsubsection{Oil and Horizontal Conflict in Nigeria}

Given the centrality of oil to the national economy the Niger-Delta has and will remain relevant to the Nigerian state because the oil produced from that region accounts for over 80 per cent of government revenues. the bulk of the country's biodiversity and some of its best human resources (IDEA, 2001:238) come from that region yet it is the most troubled and neglected region because most of the groups living there are ethnic minorities with no strong political voice neither do they control federal power before 2007. Oil conflict on this axis is felt on five fronts which are: i) between the oil producing state and the federal government, ii) between the oil producing state and the other non-oil producing states; this aspect is intricately tied to the derivation question which have been discussed above. The former is seeking for the full application of the derivation principle in the sharing of oil derived revenue among the states of the federation, while the later are strongly opposed to the full application of the derivation principle; iii) between oil producing states who share the same boundaries due to struggle over oil well; the confrontation between Bayelsa and River, and between Cross River and Akwa-lbom state over who owns some oil well between their boundary is a more recent case in point; iv) between youths in the oil producing communities and their double dealing local rulers or leaders; and $v$ ) between the various ethnic groups in the region. There are external and internal hands in the whole oil conflict that is work against the right resolution of the Niger-Delta question in Nigeria. To be specific, the Nigerian-state and multinational oil companies are fingered to be responsible for the many social contradictions within the Niger-Delta (which find expression in internecine conflicts among the component ethnic groups, clans, classes and personalities). Of course, they were the external forces that manipulated group differences responsible for igniting conflicts between the local communities so as to weaken any collective action from the people that will force the state and the MNC to come to the negotiation table.

Particularly during the era of military regime government presided over a process of conflict resolution in which government secretly settled some while at the same time instigated irate groups of different communities against each other. It is saddening to note that the interest of some of the so-called leaders of most of the groups were focused on achieving short term gain rather than on sincerely drawing attention to the actual plight of those localities in order to attract government attention for proper resolution of the problem mutually beneficially to all parties concerned. The long term implication of the abhorring behaviours of some of the Niger-Delta leaders was that they compromised the struggle aimed at seeking immediate relief to their problem. While a few so-called leaders continued to relish in the short-term gains they got from the government the larger proportion of the people of the Niger-Delta who had no access to government were daily drawn deeper into the tortuous pit of poverty due to exploitation and neglect. As a result corruption became amorphous in the Niger-Delta issue. Sadly, those who talked more were involved in such unwholesome act than those who did not. This is the tragedy of the Niger-Delta (Ibodje, 2008:173-4).

In most societies, access to the state and its leadership confers some advantages, but it can literally be a matter of life and death in impoverished countries like Nigeria. Those left out of the rent-seeking opportunities (Darren and Lewis, 2010:377-8) or patron-client network had to struggle extra-hard to live the decent life they desired. Struggling to survive outside this ring back then was a difficult and uphill task as everything centered around the military head of state who was 
the grand patron who decide who gets what. Working outside this ring was a sacrifice most of the Niger-Delta leaders were not ready to take. In the struggle, which oil generated local leaders had displayed a contradictory behaviour in both fuelling and settling some of the conflict in the Niger-Delta. On the one hand, some of the local leaders were covertly spurring their local communities to intensify their agitation in a bid to attract attention using whatever means possible. However in the process of seeking a resolution to the agitation the so-called local leaders were ready to compromise with the federal or state government given that the government was willing to generously grease the palms of those so-called local leaders so as assuage the furry of their subject in their communities. Unknown to the government these local leaders were in part the sponsors, instigators or master-minds of some of those violent agitations.

The discovery by the youth that their local leaders were double dealing and using them to live better life while the rest of the community wallow in poverty and neglect lead to the gruesome murder of four Ogoni chiefs. The federal government in response to this atrocity crucified Ken Saro Wiwa based on trump-up charges that he and his associates master-minded the killing of the four conservative Ogoni leaders in Gokana. There is no doubt that the killings of the Ogoni leaders were brutal as these men were reportedly attacked by a mob and beaten and hacked to death, but the precise chain of events leading to the murders is a source of great controversy. It should be noted that the actions of some if not most of the militant leaders, leaders of thought and traditional leaders of the people of the Niger-Delta exhibited a character that seemed to reflect a strong communal loyalties yet, one with a strong amoral civic realm (Darren and Lewis, 2010:376). Hence the entire struggle and genuine focus of the different groups to win the contestation in such a manner that government response will be directed at balancing the skewed pattern of resources extraction and distribution to the benefit of the whole Niger-Delta was compromised. It is this dialectical, albeit paradoxical, combination of threats and opportunities that make the Niger-Delta the phoenix of Nigeria (IDEA, 2001:238-257).

\subsubsection{State Response in Resolving the Persistent Oil Conflict in the Niger-Delta}

Conflict is an inevitable aspect of human interaction, an unavoidable concomitant of choice and decision...the problem then, is not to count the frustration of seeking to remove an inevitable but rather of trying to keep conflict in bounds (Zartman, 1997:197). Conflict resolution includes not only settling disputes but also abating a conflict (reducing its intensity) isolating a conflict (inhibiting third parties from intervening diplomatically or militarily in support of disputants), stopping armed hostilities (Hans cited in Ziring et al., 2005:318-9). For Alistair, (2003:107) conflict resolution subsumes the methods and process of negotiation, arbitration, and institutional building which promotes the peaceful ending of social conflict and war. Taking a contrary path will only aggravate the conflict.

Ironically, instead of the Nigerian government to take the right path to resolving the agitations the government rather choose the path of alienating the parties involved; at some stage the government resorted to violence against the people of the Niger-Delta. The pattern of violence adopted by the government and its servitors was expressed in three dimensions. The first form of state action was that of harassment against outspoken community leaders through the tactic of surveillance, arrest and detention. The second reaction of the government was in the form of encouraging conflict amongst oil producing communities. The existence of these conflicts gave the government ample reason to carry out reprisal attacks in the pretext of managing those conflicts. The third method utilized by the state took the form of extrajudicial killing presided over by the government (IDEA, 2001:248). These methods rather proved counter-productive as representatives of the given categories of the countervailing interests employ different survival tools to advance their course. (Natufe, 2001:1).

The unethical method adopted by the government coupled with the principles upon which each contesting group honed-on only fuelled their struggle and antagonism between the Niger-Delta and the government. The intensification of antagonism between the people (the oppressed), MNCs and the government was evidenced by the escalation of militancy as an aftermath of the assassination of Ken Saro-Wiwa and his compatriots against the state. The public hanging of Saro-Wiwa and his compatriots represented a high-water mark of oil conflict in Nigeria. Aside from this dastard act, the wanton destruction of lives and properties in Odi town by the Obasanjo administration represent a recent replication of the use of violent approach by the government to (resolve) manage oil conflict in the Niger-Delta region.

The failure of the government both at the state and federal levels to appropriately resolve the oil-conflict question in a manner that is mutually beneficial to the government and those communities brought into the arena new actors and groups with different and conflicting perceptions of the problem and the measures to be adopted to resolve the lingering problem. The conflicting perception and lack of synergy on the ideal strategy to resolve the problem further created the problem of evolving an appropriate approach to the resolution of the issues (Ibodje, 2008:169). This failure gave room for local groups to adopt a violent dimension with the Kaiama Declaration of 11 December, 1998 by ljaw youth. The declaration by the youth was aimed at provoking affirmative action from the government to act responsibly by facilitating 
political participation and a clean environment (IDEA, 2001:248) that had been degraded by years of oil exploration but not necessarily for the enforcement of the rights of the Niger-Delta people for resource control in its real sense. The ultimatum that was given to the multi-national oil companies to either clean the environment or leave ljawland was however seen by the then military government as an affront on its authority. The ensuing swift and brutal response by the state culminated into the so-called Egbesu war.

It is of the essence to note here that the reaction of the government to the persistent oil conflict in the Niger-Delta is not all predicated on violent reprisal. Even with the contested and some time controversial action of government, the state had responded to the Niger-Delta question by establishing the now defunct OMPADEC. This organization was saddled with the responsibility of developing the Niger-Delta region via the extensive provision of critical infrastructures such as good roads, school, and health facilities, among others. Although the action of government was appropriate but the topdown nature of state action in that direction allowed a disconnect between the beneficiaries of those facilities and the organization. With the establishment of the OMPADEC, government provided a 3\% monetary allocation for the organization to effectively perform its development responsibilities in the Niger-Delta region. Based on the $3 \%$ commitment, it was expected that the commission would be receiving about one billion naira (\$5omillion) every month from the federation account (Ibeanu, 2008).

Sadly however, the entrenched corruption that engulfed the Nigerian state impeded the commission from accessing fully its 3 per cent monthly allocation as many invisible hands were poaching on its funds. Apart from external poaching on the allocated funds OMPADEC management corruption also contributed to the inability of the OMPADEC to discharge its responsibility to the Niger-Delta communities. In 1996, its inaugural board chairman was removed from his role in OMPADEC due to the allegation that he corruptly enriched himself of the funds of the OMPADEC (Wikipedia, 2013). Although one cannot out divorce external hands of inhibiting OMPADEC capacity to satisfactorily perform its responsibility. Despite the poaching on its funds, the commission was still able to access $\$ 250$ million in 1993 and by December of 1997 the commission had accessed and expended a total of $\$ 870$ million yet physical result in terms infrastructural development of the region was regrettably poor. Evidently, strangled by corruption and poor performance the commission was unable to achieve its objective of transforming the Niger-Delta region; as a consequence this strategy could not ease the people's agitation. Due to the abysmal performance of the OMPADEC, the newly inaugurated government of Obasanjo scrapped the commission and in its place established the NNDC which took off in January, 2001 with a revenue profile as good as its predecessor (Ibeanu, 2008).

It is apposite to note that the quest by the hitherto ruling hegemonic group to systematically keep the Niger-Delta region subservient only added to the smoldering heat of the Niger-Delta people's legitimate discontent. This was evident in the manner the federal state was involved in oil extraction, fiscal relations and outright inhibition of indigenes of the Niger-Delta extraction from holding key sensitive political positions in Nigerian. To show their discontent openly against this restriction the Niger-Delta governors triggered by the adoption of sharia law in most states in Northern Nigeria relaunched the campaign for resource control premised on the practice of true federalism. The repercussion of the shift of the struggle from local community level to militant engagement and then to the higher political realm of the governors of the oil-producing state indicated that the struggle was no longer an issue to be shoved aside easily and treated with harsh reprisal as the federal government had done before. By 2001, the federal government headed to the Supreme Court with a suit against the governors of the oil-producing state. In the case brought before the court the federal government was seeking the interpretation of S12 (2) of the constitution relating to who should control the entire area designated as territorial waters of Nigeria. Evidently, the legal suit was instituted as a counter against the Niger-Delta governors' demand for resource control.

After a slightly prolonged legal debate the court declared its judgment in favour of the federal government. The implication of the judgment did not only result in the reduction of the revenue of some of the oil-producing state but also led to loss of control of those areas they hitherto lay claim to which guaranteed them a higher share of revenues from the use of the derivation principle. The outcome of the Supreme Court declaration did not only aggravated the on-shore offshore question but fuelled militancy activities with significant disruption of oil production. It also intensified the agitation by the governors of the oil-producing for resource control on the other hand. All these significantly shook the foundation of federal relations due to the bitterness the judgment stirred-up. The impact of the divergent groups' pressure only further tensed and strained the Nigeria polity with severe and damaging impact on the investment drive of the Obasanjo administration, the economy and socio-political relations. The outburst that trailed the Supreme Court declaration on the matter fundamentally made it clear that there was the need to devise a more consensus based political solution as a compliment to the expressed legal declaration to the resolution of some of the most persistent problems associated (Jega, 2008:205) with oil resources extraction and revenue distribution among and between tiers of governments in Nigeria. 
The evident abysmal outcome of the old tactics utilized to resolve the persistent question of conflict in the NigerDelta informed late President Yar'Adua in 2009 to implement the amnesty (Premium Times, 2012 and Aluede, 2012) programme (a warrant granting release from punishment for an offense) to the infrastructural development of the NigerDelta strategy of the NNDC. The amnesty offer exonerated the Niger-Delta militants of any offence against the state on the condition that they discontinue, and lay down their arms under the Disarmament, Rehabilitation and Reintegration Programme (DRRP). The amnesty program facilitated a significant reduction in the spate of militant attacks on oil installation. Due to the reduction of attacks on oil installation by repentant militants Nigeria now saves about N34 billion per day (The Sun, 2013). As at October, 2012 the amnesty programme had registered a total of 30, 000 militant for the DRRP (Premium Time, 2012) of the federal government. The amnesty program included a training program for the repentant militant whose activity in the Niger-delta creeks was almost crippling the Nigerian economy. The training program is aimed at developing the entrepreneurial capacity of the militant such that they are better prepared to be self employed and live a life free of crime.

Although, at first, the amnesty offer of the government was received with skeptism because of past state insincerity; however with Yar'Adua's administration's persistence and openness more militants willingly gave up arm struggle and embraced the government amnesty programme. The overwhelming re-election of Goodluck Jonathan, a son of the Niger-Delta from Bayelsa state, as the president of the Federal Republic of Nigeria helped to strengthen the credibility of the amnesty programme. Evidently, the amnesty programme in part contributed in reducing significantly the disruptive violent agitation that was hitherto a recurring decimal in the Niger-Delta. The ascendancy of Goodluck Jonathan as president of the federal republic of Nigeria also symbolized a significant opening of the political space in which all groups in Nigeria had a right to aspire to be president if they work hard at it in the right manner. Although this programme has not eradicated violence and criminality in the Niger-Delta complete it has nonetheless allowed the federal and state government room to develop key infrastructure essential for improving the living conditions of the NigerDelta people. This is aside from the human development character of the amnesty programme of the federal government in the region.

\section{Conclusion}

It is noteworthy to state that the struggle by the Niger-Delta people associated with oil is premised on the need to correct the perceived abnormally in the sharing of oil revenues. Despite the region oil revenue contributes a significant chunk to federal revenues the region continued to be short-changed in revenue allocation and infrastructural development. This was the source of the people's frustration which was expressed through agitations. These agitations were occasioned by the degradation ecosystem, the environment and the unfair redistribution of the revenues derived from oil. Oil conflict had a two prong dimensions that adversely impacted on peaceful federal relations. The Niger-Delta agitations had originally been peacefully but it latter transmuted into violent conflict due to the manner the hitherto ruling hegemonic group handled it. Due to poor handling of the issue, oil conflict resulted in the emergence of different local militias that were effective in killing, destroying and disrupting oil production activities. The general insecurity the struggle birthed impacted negatively on the local and national economy as both oil production and the associated revenue derived from oil declined. The ultimate consequence was that oil conflict undermined Nigeria's development process and strained relations between the dominant groups and the minorities of the Niger-Delta region.

The hitherto violence option adopted by the government in response to the various agitations relating to perceived injustice in the Niger-Delta region represented federal government's administration of a bad medication to a serious ailment. It also reflected federal government blatant disrespect of the rights of the peoples to access vital economic incentive from oil production despite the Niger-Delta bearing the harsh externalities of oil production. To worsen matters, the pattern of political engagement and participation was not inclusive to allow for group engagement in resolving the problem in an amiable and constructive manner. As a result, the Niger-Delta people were deprived of a clean environment needed to improve their socio-economic activities so as to better their living condition.

In seeking to resolve the growing agitation or conflict the state always craftily opted for that solution it thought will be beneficial to government alone; this self-centric focus only further compounded an already complex situation. Although the state continued to use the apparatus of force to win over the struggle it however continued to lose the peace it need to extract, produce, distribute and generate significant revenues from oil. Aside from the use of force the state adopted the infrastructure development strategy via the establishment OMPADEC to resolve the Niger-Delta question. This was a good option in resolving in part the problem of the Niger-Delta the problem with the commission which impeded its effectiveness rest on the lack of autonomy to operate, the unilateral manner in which it conducted its activities and the amorphous corruption that surrounded the commission. Evidently, these factors combined to make the efforts of the 
OMPADEC towards developing the Niger-Delta region less than impressive.

The oil conflict in Nigeria is a recurrent decimal simply because of the inability of the divergent actors with differing interest to find the right political arena to amicably resolve the presumed contentious issues. While this paper may not want to be involved in the blame game as to who is to be blamed for allowing the situation to degenerate so badly such that it created unnecessary tension in the polity. It is however evident that the federal government (hitherto controlled by the ruling hegemony) is not guiltless in the conspiracy against the region due to her complacency not to properly resolve the Niger-Delta question but rather allowed the issue to degenerate to the state it was before the introduction of the federal amnesty. The actual implementation of the $13 \%$ derivation, the proper monitoring, funding, and grant of autonomy to the Niger Delta Development Commission (NDDC), and the opening of the political space helped to in part resolve the Niger-Delta frustration, exclusion and exploitation. Although these measures have combined to ameliorate the problem but have not totally eradicated it, as there are still pockets of kidnappings and other forms of militant criminality in the Niger-Delta. Comparatively, the present socio-economic, political and relational environment in the Niger-Delta the center of oil conflict now has improved and it is better than it was before 2009 .

\section{References}

Abonyi, N. N and Akume, A. T (2009) Fiscal Federalism in Nigeria: A Reflection on the Derivation Principle. In: ESUT Journal of Political Science. Vol. 3, No. 3. Pp. 27-39

Adedeji, A (1966) Nigerian Federal Finance. London: Hutchinson Educational.

Allison, M (2003) Conflict Resolution. In: Iain, M and M, Alistair (ed) Oxford Concise Dictionary of Politics (2nd ed). New York: Oxford University Press. Pp.

Allison, L (2003) Community Politics. In: lain, M and M, Alistair (ed) Oxford Concise Dictionary of Politics (2nd ed). New York: Oxford University Press. Pp.

Aluede, E (2012) Presidential Amnesty Programme and the Niger-Delta War-Lords: a Correct Approach. In: Sahara Reporters. Retrieve on the 23rd of February, 2013 from www.googl.com

Duru, E. J. C (2009) Militancy and Socio-economic Development in the Niger-Delta: the Unresolved Issues. In: Journal of International Politics. Vol. 5 (1\&2). Pp. 255-269.

Darren, K and P, Lewis (2010) Nigeria. In: Mark, K., J, Krieger and W. A, Joseph (ed) Introduction to Comparative Politics (5thed). Boston, MA: Wadsworth Cengage Learning.

Egwaikhide, F. O and Omo, A, (1999) Oil Production Externalities in the Niger Delta: Is Fiscal Solution feasible. Nigeria Economic Society.

Eliagwu, J (2005) Crises and Conflict Management in Nigeria since 1980. In: Yakubu, A. M., R. T, Adegboye, C. N, Ubah and B, Dogo (ed) Crises and Conflict Management in Nigeria since 1980. Kaduna: NDA . Pp.

Ekpekurede, W (2005) Conflict and Crises in Nigeria: A Theoretical Analysis. In: Yakubu, A. M., R. T, Adegboye, C. N, Ubah and B, Dogo (ed) Crises and Conflict Management in Nigeria since 1980. Kaduna: NDA. Pp.

Gandu, R (2005) Conflict: Its Language and Lessons. In: Yakubu, A. M., R. T, Adegboye, C. N, Ubah and B, Dogo (ed) Crises and Conflict Management in Nigeria since 1980. Kaduna: NDA. Pp.

Ibeanu, O (2008) Doves, hawks and Vultures: Oil Politics in the Niger-Delta. In: Oyovbaire, S (ed) Governance and Politics in Nigeria: The IBB and OBJ Years. Ibadan: Spectrum Books Limited. Pp.

Ibodje, S. W. E (2008) Oil and the Niger-Delta. In: Oyovbaire, S (ed) Governance and Politics in Nigeria: The IBB and OBJ Years. Ibadan: Spectrum Books Limited. Pp.

IDEA, (2001) Democracy in Nigeria: Continuing Dialogue(s) for Nation-Building. Being a Capacity-Building Series 10. Sweden.

Jega, A. M (2007) Democracy, Good Governance and Development in Nigeria. Ibadan: Spectrum Books.

Natufe, O. I (2001) Resistance Politics: An Essay on the Future of Nigeria. Being A Paper Presented at the International Conference on The Challenges and Opportunities of Globalization at the Dawn of the Millennium Organized by the African Studies Programme Howard University, Washington, D.C., USA. April 11 - 14, 2001.

Premium Times, (2012) Nigeria Enlists 30,000 Ex-militants in Presidential Amnesty Programme. Retrieved on the 23 $3^{\text {rd }}$ of February, 2013 from www.google.com

The 1999 Constitution of the Federal Republic of Nigeria.

The Sun Newspaper, Amnesty Programme: A Huge Success. The Sun Newspaper of January $2^{\text {nd }}, 2013$. Retrieved on the $23^{\text {rd }}$ February, 2013 from www.google.com.

Whitefield, S (2003) Collective Action Problem. In: Iain, M and M, Alistair (ed) Oxford Concise Dictionary of Politics (2nd ed). New York: Oxford University Press. Pp.

Wikipedia (2013) Albert Horsfall. Retrieved on the 23rd February, 2013 from www. wikipedia.com

Zartman, W (1997) Governance as Conflict Management: Politics and Violence in West Africa. Washington, D.C: Brookings Institution Press.

Ziring, L., R. R, Riggs and J. C, Plano (2005) The United Nations: International Organization and World Politics (4th ed). Belmont, CA: Thomson Wadsworth. 